С. Б. Токарь

\title{
ОРГАНІЗАЦІЯ САМОСТІЙНОЇ РОБОТИ МАЙБУТНІХ ПІЛОТІВ У ПРОЦЕСІ ВИВЧЕННЯ АНГЛІЙСЬКОЇ МОВИ
}

\begin{abstract}
Токарь Є. Б. Організація самостійної роботи майбутніх пілотів у процесі вивчення англійської мови.

У статті йдеться про актуальність самостійної роботи як складової навчальновиховного процесу загалом і підготовки майбутніх пілотів 3 англійської мови зокрема. Закцентовано на тому, що самостійна робота формує у студентів уміння розв'язувати завдання й організовувати та реалізовувати власну діяльність без стороннього керівництва й допомоги. Виокремлено три етапи в організації самостійної роботи студентів авіаційного профілю 3 іноземної мови. Коротко проаналізовано види самостійної роботи, що можуть бути запропоновані під час вивчення англійської мови в авіаційному навчальному закладі.
\end{abstract}

Ключові слова: самостійна робота, ефективність, етапи організації самостійної роботи, види самостійної роботи, керівництво й контроль.

Токарь Е. Б. Организация самостоятельной работы будущих пилотов в процессе изучения английского языка.

В статье идет речь об актуальности самостоятельной работы как составляющей учебно-воспитательного процесса в целом, так и подготовки будущих пилотов в частности. Акцентируется внимание на том, что самостоятельная работа формирует у студентов умение решать задачи, организовывать и реализовывать собственную деятельность без постороннего руководства и помощи. Выделяются три этапа в организации самостоятельной работы студентов авиационного профиля по английскому языку. Кратко анализируются виды самостоятельной работы, которые могут быть предложены во время изучения английского языка в авиационном вузе.

Ключевые слова: самостоятельная работа, эффективность, этапы организации самостоятельной работи, виды самостоятельной работи, руководство и контроль.

Tokar E. B. Organization of future pilots's self-study work in the process of learning English.

The paper deals with timeliness of self-study work as a part of educational process in general and future pilots' training in particular. It states that continuing integration of science, education and manufacture requires training creative specialists whose educational activity gradually changes into professional one. The article points at the fact that self-study (c) Є. Б. Токарь, 2016. 
work forms students' ability to solve tasks and develops skills to organize and realize own activity without outside management and assistance.

The article emphasizes that students' self-work is characterized by developing student's knowledge and skills necessary for solving educational tasks as well as forming mental set on systematic knowledge acquisition and skills to get oriented in scientific information. It is also considered to be an important factor of student's self-organization in mastering methods of professional activity and behavior. The effectiveness of students' selfwork depends on conditions of its organization, variety of tasks, students' motivation, individual approach to its organization, feedback and a number of other factors.

Three stages in the organization of aviation students' self-study work in English are distinguished. Preparatory stage is aimed at working out recommendations and tasks for students. During the main stage students do the tasks, and the final stage is connected with checking, discussing the mistakes, correcting them.

This paper also focuses on short analysis of different kinds of self-study work that can be used while studying English in an aviation educational institution. They are home reading, which is mainly focused on texts having professional character, taking part in student's conferences, listening, writing essays, making projects. It is emphasized that usage of information technologies for self-study work is also an important element contributing to the effectiveness of future pilots' training.

Key words: self-study work, effectiveness, stages in the organization of aviation students' self-study work, kinds of self-study work, management and control.

У сучасних умовах розвитку суспільства й реформування освітньої системи в Україні перед вищою школою постає завдання підготовки високоосвічених спеціалістів, здатних до прийняття нестандартних рішень. Зростання рівня інтеграції освіти, науки і виробництва ще більшою мірою вимагає підготовки та формування творчої особистості фахівця, поступового перетворення навчальної діяльності студента у професійну діяльність, що, своєю чергою, можливе за умови пошуку ефективних методів і засобів навчання, розробки нових технологій викладання, підвищення ефективності навчання загалом, розвитку у студентів самостійності, здатності до самоорганізації й самоконтролю. Саме самоосвіта здатна забезпечити постійний ріст професійної кваліфікації і самовдосконалення фахівця, сприяє вдосконаленню стилю діяльності, спонукає до творчості. Отже, завдання вищої школи - виховання спеціаліста, спроможного постійно вдосконалювати свої професійні знання й навички.

Сучасна освітня програма підготовки майбутніх фахівців 
пропонує велику кількість годин для самостійної роботи, значно зменшуючи частку прямого інформування студента й розширюючи застосування інтерактивних форм роботи студента під керівництвом викладача. Підготовка майбутніх пілотів 3 англійської мови не $є$ винятковою в цьому контексті, оскільки для майбутніх авіаційних фахівців особливо актуальним $є$ формування особистості, здатної до виконання успішної, продуктивної й ефективної професійної діяльності з використанням засобів іноземної мови. Адже, як відомо, згідно 3 документами ІКАО переговори між літаком і наземними службами в міжнародному повітряному просторі слід вести англійською мовою. Самостійна робота студентів при вивченні професійної англійської $є$ невід’ємною складовою навчального процесу, має стати основою здобуття знань і важливим фактором засвоєння навчального матеріалу. Метою самостійної роботи студентів $\epsilon$ формування в них уміння самостійно розв'язувати завдання, здатність організовувати й реалізовувати власну діяльність без стороннього керівництва й допомоги [2].

Теоретичні питання організації самостійної роботи студентів висвітлені у працях багатьох науковців, як-от: А. Алексюка, Ю. Бабанського, В. Безпалька, П. Підкасистого, А. Петровського, О. Леонтьєва, К. Платонова, С. Рубінштейна, О. Біляєва, Л. Паламар, М. Пентилюк, К. Плиско. Водночас із переглядом норм навчального часу, відведеного на аудиторну й самостійну роботу студентів, розвитком інформаційних технологій, вимоги до неї постійно змінюються, що сприяло розробці нових методик, форм, технологій окресленого напряму. Це відображено в наукових студіях Г. Железовскої, Ю. Карякі, В. Козакова, Т. Лободи, Л. Морської. На сучасному етапі є низка досліджень організації самостійної роботи 3 іноземної мови у вищих закладах освіти, зокрема вивчалися: методика організації самостійної роботи студентів молодших курсів (А. Капаєва); управління самостійною навчальною діяльністю дорослих (Г. Бурденюк); самостійна робота 3 філологічного читання 
(Г. Рубцова), із засвоєння нових граматичних явищ (О. Брусяніна); розвиток навчальної автономії студентів мовних спеціальностей (Л. Трофимова, Т. Тернових); інформаційно-технологічна підтримка щодо організації самостійної роботи (А. Слизаров); організація самостійної роботи 3 англійської мови 3 використанням мовного портфеля (Н. Ягельська). Попри значний інтерес дослідників до проблеми на сучасному етапі питання організації ефективної самостійної роботи майбутніх пілотів у процесі вивчення англійської мови не знайшло належного відображення в сучасній методичній літературі.

Проблема самостійної роботи полягає передовсім у відсутності єдиного наукового підходу в іiі розв’язанні. Поняття «самостійна робота» розглядається і як форма організації, і як метод, і як засіб навчання, і як вид навчальної діяльності (Л. Вяткин, М. Гарунов, M. Підкасистий). Невизначеність у тлумаченні цього поняття негативно впливає на лише на загальне уявлення, а й на розуміння того, як найкраще організувати самостійну роботу студентів і як нею керувати.

Під самостійною роботою, услід за Н. Ягельською, розуміємо форму організації й реалізації навчально-пізнавальної діяльності студентів, яку скеровує i контролює викладач чи сам студент відповідно до програми навчання й індивідуальних потреб на аудиторних заняттях або в позааудиторний час задля оволодіння професійними знаннями, навичками й уміннями та для самовдосконалення [5, с. 7]. Як бачимо, авторка розглядає самостійну роботу як під час аудиторних занять, так і поза ними, а контроль за їі виконанням здійснюють обидва учасники навчально-виховного процесу (викладач і студент). При цьому дослідниця не акцентує на провідній ролі тієї чи тієї сторони.

Більш чіткою є позиція Л. Вяткіна, що під самостійною роботою розуміє такий вид діяльності, при якому в умовах систематичного зменшення безпосередньої допомоги викладача виконуються 
навчальні завдання, що сприяють усвідомленому й міцному засвоєнню знань, умінь i навичок формування пізнавальної самостійності як риси характеру студента [1].

На думку П. Підкасистого, для самостійної роботи студентів характерні такі ознаки: 1) формує в того, хто навчається, на кожному етапі його просування від незнання до знання необхідний обсяг і рівень знань, навичок i вмінь для розв'язання пізнавальних завдань; 2) забезпечує психологічну установку на систематичне поповнення своїх знань і вироблення вміння орієнтуватися в потоці наукової інформації; 3) є важливою умовою самоорганізації в оволодінні методами професійної діяльності, пізнання й поведінки; 4) є знаряддям педагогічного керівництва й управління самостійною пізнавальною та науково-виробничою діяльністю у процесі навчання [4].

Ефективність самостійної роботи у процесі навчання залежить від умов іï організації, форми та характеру завдань, логіки викладу завдань і т. ін. Як зазначає Ю. Лазуткіна, успіх самостійної навчальної роботи залежить від таких чинників: 1) поєднання різноманітних видів самостійних робіт і керівництва самим процесом; 2) змісту роботи і форми їі виконання (зацікавленість студента, бажання довести роботу до кінця); 3) індивідуального підходу до організації самостійної роботи; 4) надання детальних рекомендацій; 5) підтримання зворотного зв'язку з викладачем [3, с. 267].

Систематичні заходи, спрямовані на організацію самостійної роботи студента, сприяють активізації пізнавальної діяльності і формуванню самостійності як риси характеру. Звідси, відповідно, вважаємо, що в організації самостійної роботи студентів авіаційного профілю з іноземної мови доцільно виокремити такі етапи:

1. Підготовчий. У межах цього етапу викладач готує методичні рекомендації й завдання для самостійної роботи, ознайомлює студентів зі структурою навчально-методичного посібника для самостійної роботи, спрямовує студентів у зазначеному напрямку. Студенти усвідомлюють структуру організації навчального матеріалу, 
самостійно ставлять мету і складають план самостійного навчання.

2. Основний. Студенти виконують завдання, а викладач за необхідності надає консультації в позааудиторний час.

3. Підсумковий. Викладач перевіряє виконання завдань студентами, консультує стосовно помилок, організовує обговорення проблемних моментів. Студенти презентують свої роботи, творчі завдання, есе і т. ін., усвідомлюють помилки, здійснюють роботу щодо їх виправлення й усунення.

Розглянемо детальніше види самостійної роботи, що можуть бути запропоновані для вивчення англійської мови в авіаційному навчальному закладі. Викладач передовсім повинен ознайомити студентів 3 актуальністю, метою і завданнями вивчення професійної англійської, іiі місцем, роллю і значенням у професійній підготовці, визначити загальний обсяг навчальної дисципліни та обсяг розділів і тем на поточний семестр; ознайомити 3 програмою навчальної дисципліни; пояснити зміст i структуру тематичного плану, послідовність вивчення тем; представити методику самостійного відпрацювання практичних занять; ознайомити 3 матеріалом, який винесено на модуль; надати основну і додаткову літературу до кожної теми; уточнити форми і методи контролю знань студентів; повідомити графік проведення консультацій та ін. Для самостійного опанування матеріалу 3 професійної англійської викладач надає студентам розроблені методичні матеріали різного рівня і призначення, що передбачають також можливість проведення самоконтролю з боку студента. Одним із видів самостійної роботи студентів є домашнє читання професійно зорієнтованих текстів, які потребують чи то. повного перекладу, чи то перекладу окремих слів, виразів, термінів. Перевірити виконання такого завдання можна шляхом опитування лексичного матеріалу, запитань стосовно змісту. Цей вид діяльності поглиблює знання з основного предмету й англійської мови.

Іншим видом роботи, що ним активно послуговуються в Кіровоградській льотній академії, є участь студентів у конференції, 
тези для якої готуються англійською мовою. Студенти публікують результати власних досліджень або аналізують і узагальнюють здобутки інших, виступають на конференції й обговорюють свої ідеї 3 іншими учасниками. Це розвиває як науковий потенціал студента, так і його ораторські вміння. Викладач лише перевіряє наявність помилок у тезах доповіді, обговорює та виправляє їх.

Для розвитку вмінь аудіювання в самостійній роботі студентів доцільно використовувати вправи (умовно-комунікативні, комунікативні; рецептивно-репродуктивні, рецептивно-продуктивні; 3 повним, частковим, мінімальним керуванням; без ігрового компонента, з рольовим ігровим компонентом, 3 нерольовим ігровим компонентом; без опор, зі спеціально створеними опорами, з природними опорами; індивідуальні, парні) на: прослуховування аудіотексту й визначення правильності / хибності запропонованих тверджень; прослуховування аудіотексту і вибір серед наведених предметів / явищ / тверджень тих, про які йшлося в аудіотексті; прослуховування аудіотексту й вибір правильної відповіді серед запропонованих щодо його змісту; прослуховування аудіотексту та розташування тверджень у порядку, який відповідає змісту прослуханого аудіотексту; прослуховування аудіотексту і заповнення таблиці на основі змісту прослуханого аудіотексту; прослуховування аудіотексту й виправлення помилки в короткому викладі його змісту; прослуховування аудіотексту і заповнення пропусків у друкованому варіанті тексту; відповіді на запитання щодо змісту прослуханого аудіотексту; переказ змісту прослуханого аудіотексту кількома реченнями; визначення основної i другорядної інформації у прослуханому аудіотексті; прослуховування аудіотексту та визначення отриманих нових знань; визначення фактичної й оцінної інформації у прослуханому аудіотексті; формулювання основної думки автора прослуханого аудіотексту, обгрунтування власного ставлення до неї. Зазначимо, що в самостійній роботі варто практикувати різні види аудіювання: ознайомлювальне, вибіркове, 
детальне. На нашу думку, значна увага в самостійній роботі на I-II курсах повинна приділятися ознайомлювальному й детальному аудіюванню, тоді як на старших курсах дедалі більшу увагу треба приділяти детальному аудіюванню, передусім критичному рівню розуміння аудіоповідомлення, який передбачає розуміння й аналіз імпліцитної інформації аудіотексту.

У контексті викладання іноземної мови актуальними на сьогодні $\epsilon$ також такі форми самостійної роботи, як написання есе й виконання проектів. Такі завдання формують у студентів уміння критично мислити, приймати власні рішення, доводити власну позицію, що $є$ вкрай необхідним у майбутній професійній діяльності. До того ж сучасна методика викладання іноземної мови приділяє велику увагу креативній, творчій діяльності студентів на заняттях i вдома. Інтенсифікація цього процесу відбувається завдяки впровадженню інтерактивних методик, до яких можна віднести і метод проектів, що дає змогу виявити самостійність у виборі джерел інформації, способу ii викладу й презентації. Проектна методика уможливлює індивідуальну роботу над темою, яка викликає найбільший інтерес у кожного учасника проекту, що, поза сумнівом, спричиняє підвищену мотивовану активність студента. Це ідеальна нагода здобувати й застосовувати знання 3 англійської мови творчо, реально відчути власні досягнення, розвивати мовні навички й уміння на практиці.

Сучасна методика викладання професійної англійської приділяє велику увагу й застосуванню новітніх інформаційних технологій. Не винятком у цьому плані є й використання ресурсів інформаційної мережі інтернет під час самостійної роботи майбутніх пілотів. Найбільш ефективними засобами для вдосконалення знань англійської студентів-пілотів є можливості використання відеоматеріалів, що відображають надзвичайні ситуації під час виконання польотів, з подальшим аналізом їх причин і наслідків, розв'язанням завдань щодо уникнення подібного в майбутньому. Зазначимо, що використання комп'ютерних технологій для самостійної роботи - 
важлива складова ефективності навчання професійної англійської. Комп'ютеризація розвиває додаткові можливості використання інформаційних технологій і становить важливу складову навчального процесу, є елементом інформаційної структури кожного навчального закладу, а якщо враховувати доступ до інтернет-ресурсу, то й елемент глобального інформаційного середовища.

Отже, самостійна робота студентів 3 англійської мови в авіаційному навчальному закладі становить невід'ємну складову навчального процесу. Самостійна робота входить у загальний рейтинг і призначена для розвитку навичок самостійного засвоєння мовного матеріалу. Кожен із зазначених видів самостійної роботи $\epsilon$ позааудиторним і потребує від студентів наполегливої праці. Тому одним із основних завдань викладача при організації самостійної роботи студентів із професійної англійської є розробка форм і методів організації контролю за виконанням самостійної роботи. Саме в цьому й убачаємо перспективи подальших розробок проблеми самостійної роботи майбутніх пілотів у процесі вивчення англійської мови.

\section{Література}

1. Вяткин Л. Г. Уровни познавательной самостоятельности студентов педагогических вузов / Л. Г. Вяткин, А. Б. Ольнева, Г. Д. Турчин // Актуальные вопросы региональной педагогики : сб.науч.тр. - Саратов, 2002. - С. 35-38.

2. Гарунов М. Г. Самостоятельная работа студентов / М. Г. Гарунов. - М. : Знание, 1998. - $214 \mathrm{c}$.

3. Лазуткіна Ю. А. Форми та методи фахової підготовки студентів у процесі самостійної роботи на уроках з англійської мови / Ю.А.Лазуткіна // Філологічні студії : Науковий вісник Криворізького національного університету : зб. наук. праць. -2015. - Вип. 12. - С. 263-270.

4. Пидкасистый П. И. Сущность самостоятельной работы студентов и психологодидактические основы еe классификации / П. И. Пидкасистый // Проблемы активизации самостоятельной работы студентов. - Пермь, 2000. - С. 107-112.

5. Ягельська Н. В. Методика організації самостійної роботи студентів 3 англійської мови з використанням професійного мовного портфеля : автореф. дис. ... канд. пед. наук / Н. В. Ягельська. - К., 2005. - 23 с.

Стаття надійшла до редакиії 27.08.2016 p.

(C) Є. Б. Токарь, 2016. 